\title{
歯冠彫刻のための歯の形について
}

\author{
下嶺第二大日歯 (1) \\ 藍稔。川 几豊造大石司郎
}

\section{Studies on Artificial Crown Forms}

\author{
Lower Second Molar (Part 1)
}

Minoru Ai, Toyozo Kawaguchi, Shiro Oishi

\section{1.はじめに}

天然幽の形態を知ることは歯科のあらゆる分野にとつ て基本的な要件であるが，崩壊した菌冠の修復を目的と する充淖学, 補緅学にとつては天然歯形態の充分なる把 握は不可久である.その形, 大きさの程度, 顥骨との関 係については形態学的な立場 ${ }^{(-5)}$ から, 又咀噮器官の一 要素として蝢運動や歯周組織との関倸については機能的 な立場 ${ }^{6-11}$ から追及されているが，現在の段階において は天然歯形態が形態学的にもすぐれたものであるとの結 論は未だ得られていない. しかし少なくとも正常な形態 では他に障害が認められないことから，歯冠の修復にあ たつては出来るだけ元の天然歯の形になるように努めて いるのである.したがつて，ここでは作り出すための天 然歯形態の立体的, 綜合的な見方が要求され, その教育 の課程においても歯牙解剖学, 歯冠彫刻が重視されてい る. 天然歯の形を歯牙解剖学, 歯冠彫刻のための成畫に ついて見ると，各歯の特徽，ならびに形が図示されてい るが，それらの図は著者が各々の歯のあるべき形を示し たものであろう．多少の差異があつて著者により歯に対 する見方の違いがうかがわれるそここである一つの歯に ついてその形がいかなるものとして把えられているか, 又それぞれの形がどのように異なつているかを文献の上 で比較するのも天然歯形態を理解するのに参考になるも のと思われる.

今回は下凝第二大臼歯の形について検討することにし た.

* Dept. of Prosthetic Dentistry, School of Dentistry, Tokyo Medical and Dental Univ. (Director: Prof. T. Ishiwara)

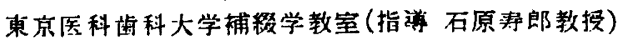

\section{2. 下顎第二大臼歯の特徵}

下額第二大目菌の形を図で比較する前に，先ずこの歯 に対して著者らの眼のつけどころがどこにあるか，即ち 形態上の重点を調べるため, 藤田 ${ }^{12}$ ，上条 ${ }^{13}$, 矢崎 ${ }^{14}$, 石上 ${ }^{151}$, Black, ${ }^{161}$, Diamond ${ }^{17}$, Schwartz ${ }^{181}$, Wheeler ${ }^{191}$ らの 8 つの成書について形に関する記载を調查した.

1) 歯冠概形に関して

（1）咬合面からみて方形をなしている

（2） 4 咬頭性

（3）歯冠全体に丸みがある

（4）隣接面からみた煩舌側の外形は平行四辺形をな 士

（5）下頡第一大臼歯上り小型

（6）咬合面からみて近心縁は直線的だが，遠心縁は 彎曲している

（7）煩舌面の外形は逆梯形をなす

2) 歯面に関して

（1）近心面は平坦だが，遠心面は豊隆している

（2）舌側而の方が煩側面より狭い

3）咬頭に関するもの

（1）近心咬頭の方が遠心咬頭より高い

（2）煩側咬頭の方が舌側咬頭より低く鈍円である

(3) 四つの咬頭はほぼ同程度の割合を占める

4）满，窩に関するもの

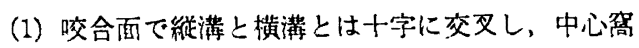
を形成する

（2）頖，舌側闻溝がある

（3）近，遠心小窩がある 


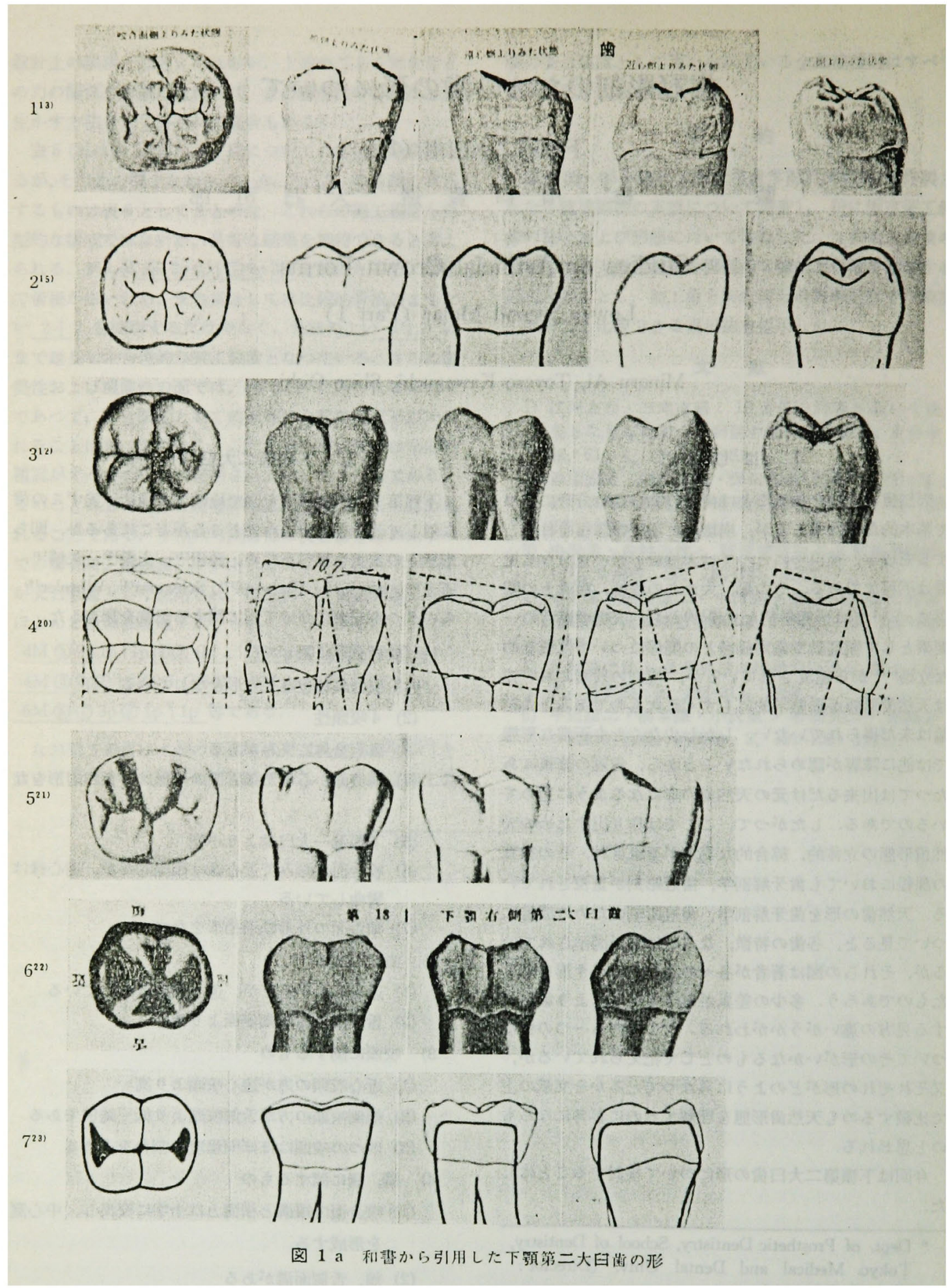




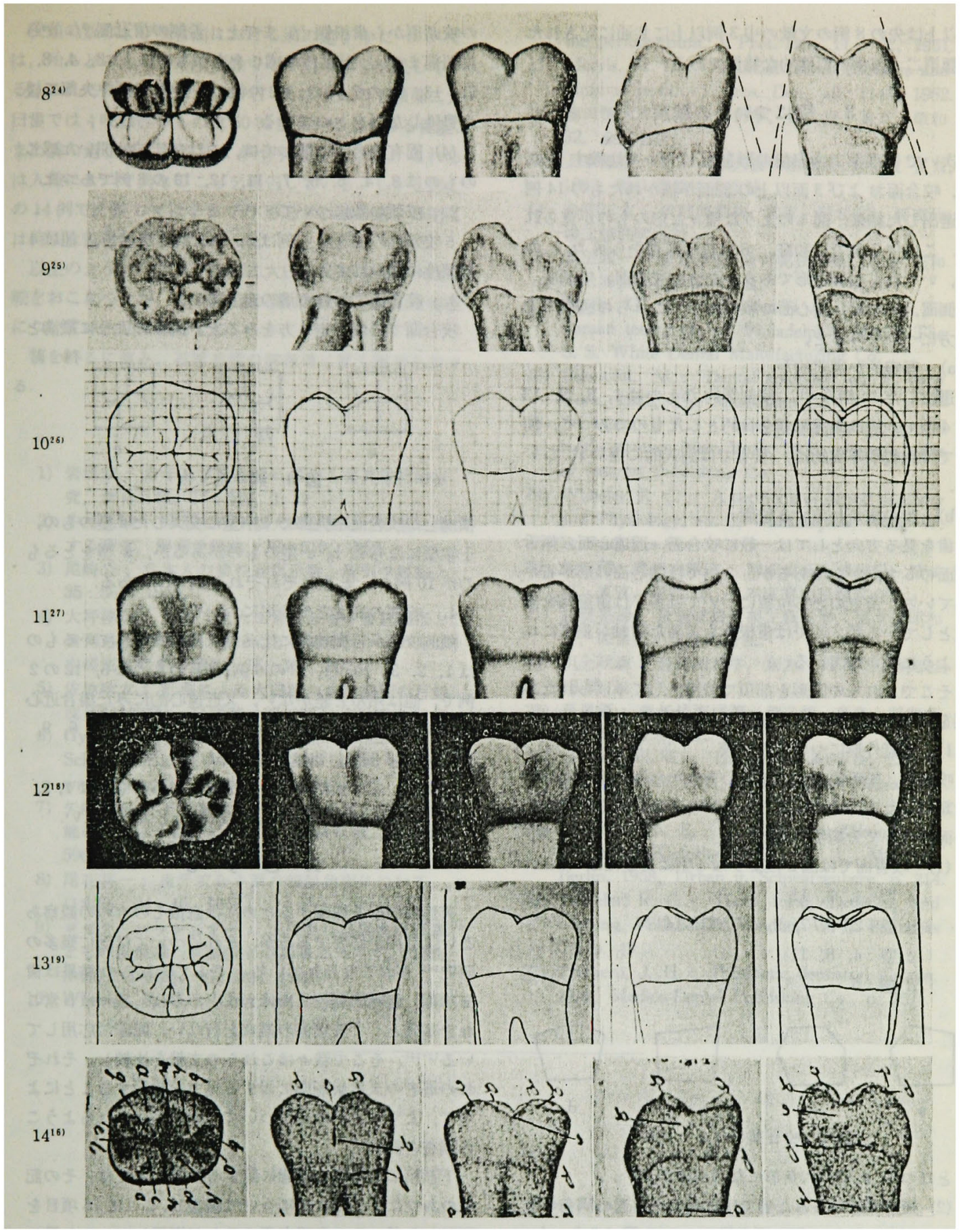

图 $1 \mathrm{~b}$ 洋書から引用した下瀬第二大臼监の形 


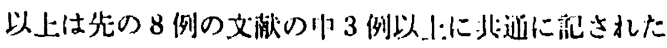
下影第二大田歯の形热的な特徽である.

\section{3. 図についての観察}

次いで下顎第二大目歯の形を図について比較するた め，咬合面および 3 面以上の側面が描かれたもの 14 例 を選出した結果，図1のような種々な形のものが見られ た.この中 7 までは和書， 8 以後は洋書から得たもの で，いずれも右側の形であり，左から咬合面，碩側面， 舌側面，近心面，遠心面の順である．これらの図形の描 き方についてみると，

a) 写実的加図式的加

選出した 14 例の中, 解剖学的なものは $1,3,9,13$ の 4 例で，他は葛冠彫刻を目的としたものであつて，前 者では比較的写実的に，後者では図式的に描かれてい る.

b）歯の描かれている位遀

歯を見る方向としては一般に咬合面，近遠心面，煩舌 側面の 5 方向からであるが， 3 例では遠心面の形が省か れている. 菊冠のとる位置については多くは歯冠軸を垂 直としているが，4では歯根をも含めた歯粙が垂直にな るように描かれている.

そこでこれらの図形を前項で特徴として挙げられた事 項を参考として観察し比校众討した。

1. 歯冠外形についての比攺

咬合而，颀舌似および近避心方问からみた齿冠外帅に は勋似した形のものが見られる。そこでこれらの外形を 各河について分耀すると，

（1）咬合淌では図2のような4型に分けたが

a 型 : $1,3,12$

b 型: $: 2,6,7,9,10,13,14$

c 型 : $4,8,11$

d 型 : 5

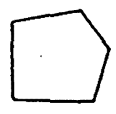

a

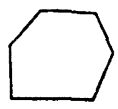

b

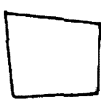

c

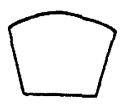

d
图 2 呚合面からみた外形

となつて b 型の六角形になるものが多い,

（2）煩舌側面からみた形では近心よりも遠心㧑角の方

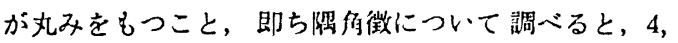

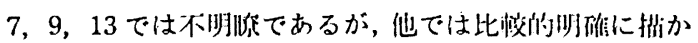
れている.

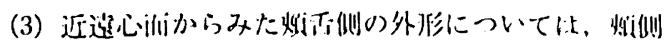

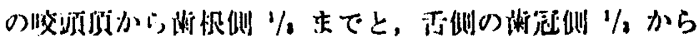
㳡项部までとが平行な感しををつものは $1 ， 3 ， 4 ， 8$, $11,13,14$ の 7 例で，この他のものは歯冠中头部で緩 く豊隆した形をとつている.

（4）固有咬合面に関しては，これが比較的關いた感し のものは $3,4,5,6,7,11,12,13$ の 8 例であつた.

2. 咬頭の数について

5 咬頭性の形をとる例は 5,9 の 2 例だけで，他は 4 咬頭性に描かれている。

3. 咬合面における㴖の走り方

晈合面での輫の走り方をみると，図3のように縦潾と

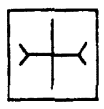

a

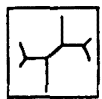

b

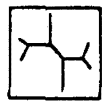

c
图 3 满の走り方

横灌とが咬合面中央部で十字型に交叉した $\mathrm{a}$ 型のもの， 十字型にならぬ b, c 型のものがあるが，a 型をとるも のが 10 例，b，c 型はそれぞれ 2 例つうつである.

4. 咬頭の高さとその形について

㛲側咬頭が舌側咬頭に比べて低目に描かれているもの は 1，2，3，10，11，13の6 例, 高目のものは 5,12の 2 例で，他は殆んど差がない，又近遠心的にみた場合近心 咬頭が 遠心咬頭上り高目のものは $1 ， 3 ， 4 ， 5 ， 6 ， 9$, 12,13 の 8 例で, 他は同程度である.

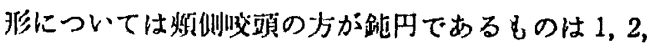
$3,7,9,10,1307$ 侧で, 他は始儿ど大望がない.

\section{4.むすび}

天然㐘の形を理解するためには㨁接そのものの钼察あ るいは訃測が必要であるが，それについては贿に幾多の 研究1-51がおこなわれている。そしてそれらの結果は歯 牙解剖，歯冠彫刻のためにもまとめら机，我々は日常こ れを基礎として天然歯の観察を行ない，臨床に忘用して いる12-2n．そこで我々はこれらの文献を比較し，それぞ れの著者の天然歯形態に対する見方を検討することによ つて,より一層歯の形についての理解がなされるようこ の調查を試みた.

下額第二大臼歯の形態に関する特徽としては，その記

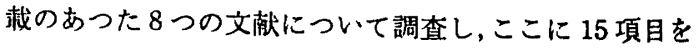
列举したが，その必要事項は殆んど網羅していると思わ れる.しかし萪の外形を14 例の图で比校した結果では

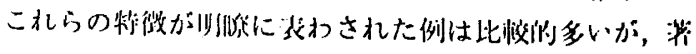
リでないしのしむのた。 


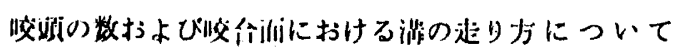
は，活んどのものが 4 咬頭性で十字型の蓝を形成してい る.これについて上条 ${ }^{211}$, 中村" 氏は邦人の下影第二大 臼菊では 4咬頭性のものは $50 \%$ を僅か比上まる程度, また篟の走り方は $70 \%$ 近くが十字型をとるが，これら は人種によって異なることを報告している.しかし図1 の 14 例で比較しては 7 までの形と 8 以後の形との間に は特別な差異は見られなかつた。

以上のように今回は下額第二大臼歯の形の大まかな比 較をおこなつたが、より詳細な検討および全体的な特徴 については次回に報告する.

稿を終るに臨み，石原教授の御指鹪に厚く謝意を表す 3.

\section{文献}

1）岩垣宏：歯牙及び歯列穹に閶する変異赫計的研 究，药科月報， $17: 519 ， 1: .37$.

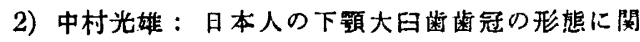
才る研究, 解剖学雑誌, $32: 510,1957$.

3）尾崎公：日本人の歯の退化示数, 解剖学雑誌, $35: 563,1960$.

4) 大坪海造：日本人成人正常咬合者の歯冠幅径と 菌列弓改び Basal Arch との関係について, 日 本矮正药科学会鹳誌, $16: 36,1957$.

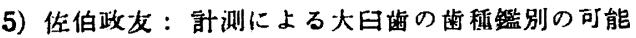

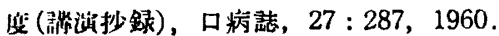

6) Gysi, A. : Handbuch der Zahnheilkunde IV, Scheff, Berlin u. Wien, 1929, Urban u. Schwarzenberg, 1-171.

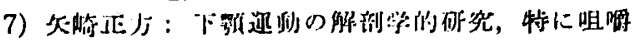

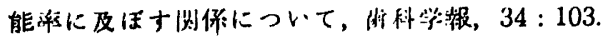
590, 707, 1929.

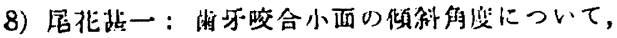
口粉志, $24: 40,1957$.

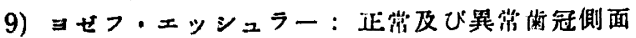

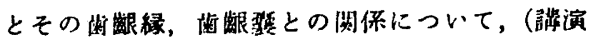
抄録), 口病誌, $16: 181,1942$.

10) Wheeler, R. C. : Complete crown form and the periodontium, J. Pros. Den. $11: 722,1961$.

11) Morris, M. L. : Artificial crown contours and gingival health, J. Pros. Den. 12:1146, 1962.

12）藤田恒太郎：歯の解剖学, 第 3 版, 東京, 昭和 32 , 金原書店. .

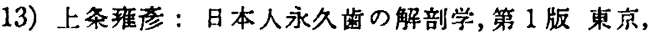
1962, 地人昰館株式会社.

14）矢崎正方：继冠影刻法, 東京, 昭和 32 , 而至化 学工業株式会社.

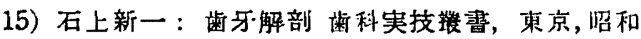
31 , 医齿薬出版株式会社.

16) Black, G. V.: Discriptive anatomy of the human teeth, 4th ed. Philadelphia, 1902, The S. S. White Dental Manufacturing Co.

17) Diamond, M. : Dental anatomy, ed. 3, New York, 1952, The MacMillan Co.

18) Schwartz, J. R. : Practical dental anatomy and tooth carving, New York, 1935, Dental Items of Interest Publishing Co.

19) Wheeler, R. C. : A textbook of dental anatomy and Physiology, ed. 3, Philadelphia, 1958, W. B. Saunders $\mathrm{Co}$.

20）柴田信・黑河内敏三：臨床蒾牙形態図説，第 4 版, 東京, 昭和 19 , 日本医書出版株式会社.

21）緗野来馬：鿪冠補緅及架工義菌学, 東京, 炤和 27 , 医蒾薬出版株式会社.

22）川上政雄：菌冠補敘学, 東京, 昭和 7, 齿苑社, 18 頁.

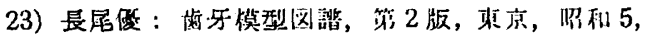
金原浐店株式全社.

24) Selbach, F. W. : Das Moderieren der Zahnkronen, Berlin, 1958, Berlinische Verlagsanstalt G. m. b. H., p. 59 .

25) DeJonge, Th. E. : Anatomie der Zähne, Zahn Mund u. Kieferheilkunde Bd. 1, München Berlin, 1958, Urban u. Schwarzenberg, p. 214.

26) Wheeler, R. C.: Tooth form, Drowing and Carving, Philadelphia-London, W. B. Saunders Co. p. 42.

27) Prothero, J. H. : Prosthetic dentistry, Cicago, 1923, Medico-Dental Publishing Co., p. 757. 